\title{
EMBRIO PENDIRIAN KOPERASI PRODUKSI SEBAGAI SOLUSI MASALAH PADA PETANI PETANI WIRATANI DESA TEGAL SAWAH KARAWANG TIMUR
}

\author{
Deddy Rusyandi \\ derusy@gmail.com \\ Erlinda Yuniarti Kasim \\ Erlynda_kasim@yahoo.com \\ Ganjar Garibaldi \\ Gjr_grbd@yahoo.com
}

\section{SEKOLAH TINGGI ILMU EKONOMI EKUITAS}

\begin{abstract}
ABSTRAK
Produktivitas hasil produksi mitra petani Wira Tani, Desa Tegal Sawah, Kecamatan Karawang Timur, Kabupaten Karawang tergolong tinggi, tetapi terdapat kendala dalam Penyaluran Produk-Produk tersebut. Kegiatan pengabdian ini bertujuan untuk membantu mitra dalam menyelesaikan permasalahan pendistribusian dan penjualan produk hasil pertaniannya. Kegiatan jangka pendek meliputi konsultasi dan pendampingan penyaluran Produk-Produk dari Wira Tani, dengan didukung oleh pendekatan kelimuan dan terapan bidang Ilmu Manejemen Pemasaran. Sedangkan kegiatan jangka panjang adalah pembentukan embrio koperasi, yaitu suatu lembaga yang dapat secara berkelanjutan mampu menyelesaikan permasalahan penyaluran ini. Upaya pendampingan memerlukan proses yang cukup lama mengingat daya tangkap para petani tentang distribusi dan koperasi dan keterbatasan waktu, di samping upaya mendirikan koperasi melibatkan instansi/lembaga lain sehingga pada periode ini tim pengabdi hanya mampu melakukan kegiatan pengabdian sampai dengan pendampingan dalam persiapan pendirian koperasi.
\end{abstract}

Kata kunci: Embrio, Koperasi, pendampingan.

\section{PENDAHULUAN}

Karawang sebagai salahsatu wilayah pertanian, dulu memiliki jatidiri dan dikenal sebagai daerah pertanian terbaik di Indonesia, kini produktivitas dan kualitas hasil pertaniannya mulai menurun, hal tersebut dikarenakan berbagai masalah diantaranya; adanya alih fungsi lahan pertanian menjadi pemukiman dan industri, serta berbagai isu lingkungan seperti pencemaran dan pemanasan global serta keterbatasan SDM dan teknologi yang diterapkan.

Fungsi Karawang sebagai penyokong utama ketahanan dan kedaulatan pangan nasional harus dikembalikan pada jatidirinya. Karawang menerapkan pengembangan paradigma baru dalam pengelolaan sistem pertaniannya. Pengelolaan melalui pola intensifikasi pertanian yang dilaksanakan secara terpadu, moderen dan ramah lingkungan. 
Pada Desa Tegal Sawah, Kecamatan Karawang Timur, tepatnya di Kabupaten Karawang, Jawa Barat, mendapati kondisi dimana pada desa tersebut terjadi proses agribisnis yang semakin produktif dalam operasinya. Di desa ini meskipun terjadi pengaruh buruk akibat penerapan pupuk kimia dan teknologi rumah kaca serta perkembangan kemajuan lainnya, yang tidak mendukung terhadap sektor pertanian, tetapi di desa ini terjadi suatu kegiatan pertanian terpadu, yang menunjang hasil produksi yang produktif.

Pada Desa Tegal Sawah, Kecamatan Karawang Timur, tepatnya di Kabupaten Karawang, Jawabarat, salah seorang tokoh petani di wilayah tersebut telah menerapkan Sistem Pertanian Terpadu dengan nama Wira Tani". Tokoh tersebut membuat Wira tani, diawali dengan menghibahkan tanah seluas 0,5 Hektar yang terbuka bagi rakyat yang (khususnya petani) sekitar untuk bergabung.

Visi-Misi Pertanian Terpadu Wira Tani terebut, sebagai mitra terbaik pemerintah dan masyarakat dalam mewujudkan ketahanan dan kedaulatan pangan nasional melalui pengembangan model pertanian terpadu ramah lingkungan yang dikelola secara profesional.

1. Mengembangkan model pertanian terpadu secara profesional (Pertanian, Peternakan, Perikanan, Lingkungan).

2. Mengembangkan pusat pelatihan, pelayanan dan konsultasi serta pembinaan kepada masyarakat tentang penerapan pertanian terpadu dengan berbagai aspek pendukungnya yang berorientasi pada keseimbangan ekosistem /lingkungan.

Kegiatan Utama Pertanian Terpadu Wira Tani, mencakup: a) Pengembangan model budidaya pertanian mencakup tanaman; holtikultura, dan tanaman pendukung lainnya, baik pada lahan terbuka dan maupun media tanam terbatas. b) Pengembangan model budi daya peternakan mencakup; sapi, kambing, kelinci, unggas dan budidaya perikanan air tawar mencakup ikan; emas, nila, patin, lele, gurami, belut, mujair. c) Pengembangan pengolahan limbah pertanian ramah lingkungan. d) Pengembangan produksi pakan ternak baik secara alamiah (penanaman) maupun melalui proses rekayasa bioteknologi. e) Pengembangan model usaha pertanian masyarakat melalui penyediaan pupuk organik, bibit unggul, alat-alat pertanian dan penyelenggaraan agrowisata (wisata pertanian). f) Pelopor Gerakan Peduli dan Pelestarian Lingkungan, dan g) Sebagai Pusat Pelatihan Pertanian Pedesaan Swadaya (P4S).

Produktivitas hasil produksi yang didapat sejak usia pertumbuhan Wiratani ini tergolong tinggi, namun demikian mereka menghadapi beberapa kendala, seperti kesulitan dalam 1) Penyaluran ProdukProduk dari Wira Tani, dan adanya kebutuhan dan Visi untuk dapat menyelesaikan permasalahan penyaluran ini, secara jangka panjang.

Dalam upaya mengatasi masalah para Petani wiratani tersebut, pengabdian berupaya memberikan solisi berupa:

1. Konsultasi dan pendampingan penyaluran Produk-Produk dari Wira Tani, dengan didukung oleh pendekatan kelimuan dan terapan bidang Ilmu Manejemen Pemasaran.

2. Dengan terdapatnya kebutuhan dan Visi untuk membentuk suatu lembaga yang dapat secara berkelanjutan mampu menyelesaikan permasalahan penyaluran ini, maka pembentukan koperasi merupakan suatu jalan keluar yang layak dan memungkinkan. Dengan didukung oleh pendekatan kelimuan dan terapan bidang Ilmu Manejemen Koperasi.

Pelaksanaan ini diharapkan dapat memberikan manfaat dalam membantu Mitra untuk dapat secara mandiri, menyeslesaikan permasalahan distribusi produk-produk yang dihasilkan oleh wiratani dengan menguntungkan. Secara jangka panjang, untuk menyelesaikan permasalahan distribusi tersebut, mitra juga terbantu dengan pendampingan pengenalan 
sampai dengan pembentukan koperasi sebagai suatu wadah yang secara berkesinambungan mengelola luaran dari produk wiratani.

\section{METODE PELAKSANAAN}

Berdasarkan hasil survey dan diskusi dengan mitra maka permasalahan yang dihadapi oleh mitra antara lain adalah sebagai berikut:

1. Penyaluran produk-produk dari Wira Tani.

2. Terdapatnya kebutuhan dan Visi untuk dapat menyelesaikan permasalahan penyaluran ini, secara jangka panjang.

\section{HASIL PENGABDIAN PADA MASYARAKAT}

Dari hasil analisis situasi dapat diidentifkasi bahwa permasalahan yang dihadapi Pertanian Terpadu Wira Tani di Desa Tegal Sawah, Kecamatan Karawang Timur, Kabupaten Karawang, Jawa Barat adalah penyaluran produk-produk dari wira tani dan terdapatnya kebutuhan dan visi untuk dapat menyelesaikan permasalahan penyaluran ini, secara jangka panjang. Solusi yang perlu dilakukan untuk mengatasi permasalahan ini adalah sebagai berikut:

1. Konsultasi dan pendampingan penyaluran Produk-Produk dari Wira Tani, dengan didukung oleh pendekatan kelimuan dan terapan bidang Ilmu Manejemen Pemasaran.

2. Dengan terdapatnya kebutuhan dan Visi untuk membentuk suatu lembaga yang dapat secara berkelanjutan mampu menyelesaikan permasalahan penyaluran ini, maka pembentukan Koperasi merupakan suatu jalan keluar yang layak dan memungkinkan. Dengan didukung oleh pendekatan kelimuan dan terapan bidang Ilmu Manejemen Koperasi.

Untuk menerapkan atau mengimplementasikan solusi yang ditawarkan tersebut, digunakan metode- metode yang meliputi: survey, kuliah (pendidikan masyarakat) dan pendampingan.

Survey Kegiatan Usaha Mitra.

Berdasarkan kunjungan tim ke Desa Tegal Sawah, Kecamatan Karawang Timur, Kabupaten Karawang, Jawabarat pada bulan Januari 2017, untuk melihat situasi dan kondisi Pertanian Terpadu Wira Tani di desa tersebut diperoleh informasi bahwa kegiatan-kegiatan yang dilakukan oleh Pertanian Terpadu Wira Tani di desa tersebut, diperoleh informasi bahwa kesulitan yang mereka hadapi saat ini adalah distribusi produk hasil pertanian yang mereka hasilkan.

Pelatihan untuk Peningkatan Wawasan Dan Keterampilan Distribusi Dan Penjualan Produk Serta Pengenalan Koperasi.

Mengingat bahwa kesulitan yang mereka alami adalah masalah distribusi maka kegiatan kami lanjutkan dengan memberikan sedikit materi terkait dengan wawasan dan keterampilan dalam mendistribusikan produk secara keilmuan. Materi-materi yang disampaikan meliputi: definisi, konsep dan sistem pemasaran; tugas manajer pemasaran, perilaku konsumen, perencanaan pemasaran, teori permintaan dan penawaran dan strategi produk pertanian.

Selain itu tim juga menyampaikan materi terkait dengan koperasi. Materi yang disampaikan meliputi: pengenalan koperasi; jenis koperasi, tujuan dan manfaat koperasi dan garis besar pembentukan koperasi.

Dari hasil penyampaian materi tersebut dan dari diskusi yang dilakukan setelahnya, Mitra terkesan dalam upaya pendistribusian produk melalui koperasi. Untuk itu maka tim sepakat untuk membantu mempersiapkan segala sesuatu hal yang berkaitan dengan persiapan mendirikan koperasi. Selanjutnya tim mengagendakan kembali kunjungan 
berikutnya untuk menyampaikan materi terkait dengan pendirian koperasi.

Pemahaman Pentingnya Pendirian Koperasi

Sebagai Solusi Jangka Panjang.

Berdasar buku Pembentukan Koperasi Tani Yang Dikeluarkan Oleh Pusat Penyuluhan Pertanian - Badan Penyuluhan Dan Pengembanagan SDM Pertanian Kementerian Pertanian 2012, bahwa Pembinaan kelembagaan petani sesuai dengan Permentan Nomor. 273 Tahun 2007 tentang Pedoman Pembinaan Kelembagaan Petani diarahkan pada peningkatan kemampuan dan penguatan kelembagaan petani menjadi organisasi yang kuat dan mandiri dalam bentuk kelembagaan ekonomi petani. Salah satu upaya pemberdayaan petani dalam rangka meningkatkan kapasitas kelembagaan petani menjadi kelembagaan ekonomi petani salah satunya dilakukan melalui pembentukan koperasi.

Untuk membangun koperasi tani yang ideal sesuai dengan tujuannya sebagai kelembagaan ekonomi yang kuat di perdesaan, diperlukan dukungan sumberdaya manusia yang berkualitas. Untuk itu diperlukan pengawalan dan pendampingan yang berkesinambungan baik dari penyuluh, kelembagaan penyuluhan serta dari dinas/instansi yang menangani koperasi di kabupaten/ kota.

Pendampingan Pendirian Koperasi

Tahapan fasilitasi pembentukan koperasi tani terdiri dari persiapan, pembentukan dan pelaksanaan serta monitoring dan evaluasi, dengan rincian sebagai berikut:

Persiapan Pembentukan Koperasi

a. Tim melakukan identifikasi terhadap Mitra untuk dikembangkan menjadi koperasi sesuai dengan persyaratan;

b. Setelah memenuhi syarat diajukan ke Kepala BP3K dan diteruskan kepada Kepala BP4K di tingkat kabupaten;

c. Verifikasi dan validasi kelayakan gapoktan yang diusulkan sebagai calon koperasi tani oleh

BP4K/Kelembagaan yang

membidangi penyuluhan bekerjasama dengan dinas/kantor yang menangani koperasi di kabupaten/kota

d. Kepala BP4K dan kepala dinas/kantor yang menangani koperasi di kabupaten/kota menyepakati gapoktan yang siap untuk difasilitasi untuk membentuk tani;

e. Daftar Gapoktan yang memenuhi syarat selanjutnya dimasukan menjadi salah satu bahan dalam penyusunan programa penyuluhan tingkat kecamatan;

f. Setelah program penyuluhan disusun, maka fasilitasi pembentukan koperasi tani menjadi bahan bagi rencana kerja penyuluh;

g. Sosialisasi oleh penyuluh tentang manfaat dan tata cara pembentukan koperasi yang dilakukan pada pertemuan berkala gapoktan untuk memberikan wawasan tentang Koperasi Tani. Kegiatan sosialisasi ini sebaiknya dengan menyertakan petugas dari dinas/kantor yang menangani koperasi;

h. Musyawarah/rembug gapoktan untuk menyepakati pembentukan koperasi tani, pada pertemuan ini sebaiknya dihadiri oleh petugas dari dinas/kantor yang menangani koperasi agar untuk selanjutnya gapoktan tersebut mendapat fasilitasi dalam mempersiapkan kelengkapan untuk membentuk koperasi;

i. Fasilitasi berupa pendampingan oleh penyuluh pertanian bersama dengan petugas oleh petugas dari dinas/kantor yang menangani koperasi. Materi fasilitasi antara lain meliputi:
1) Persyaratan dan proses pembentukan koperasi tani;
2) Struktur, tugas, tanggung jawab dan fungsi kepengurusan koperasi tani;
3) Penyiapan dokumen-dokumen kelengkapan pembentukan koperasi.


j. Pendampingan oleh penyuluh pertanian dilakukan sebagai bagian dari kunjungan penyuluh ke kelompoktani/gapoktan sesuai dengan jadwal yang disepakati bersama kelompoktani/gapoktan;

Pembentukan Koperasi Tani

a. Setelah bentuk koperasi beserta namanya telah disepakati, maka dilakukan pendirian koperasi dengan pembuatan Akta Pendirian Koperasi yang dibuat oleh Notaris yang terdaftar pada dinas/kantor yang menangani koperasi.

b. Apabila akta pendirian telah diterbitkan maka koperasi tersebut, harus memperoleh pengesahan sebagai badan hukum, apabila lingkup wilayah kerja koperasi di kabupaten/kota maka pengesahan badan hukum dapat diperoleh dari dinas/kantor yang menangani koperasi di kabupaten/kota.

Pelaksanaan

Setelah koperasi tani terbentuk, maka masih diperlukan adanya fasilitasi dari berbagai pihak, agar kelembagaan tersebut mampu mengembangkan usaha tani berskala ekonomi yang menguntungkan dan efisien. Untuk itu fasilitasi yang diperlukan antara lain:

a. Perencanaan usaha;

b. Pengembangan bidang usaha diantaranya:

1) Bidang usaha yang menyediakan dan menyalurkan sarana produksi berupa alat-alat dan mesin- mesin pertanian;

2) Bidang usaha dalam produksi komoditas pertanian;

3) Bidang usaha industri pengolahan hasil pertanian (agroindustri);

4) Bidang usaha pemasaran hasil-hasil pertanian; dan

5) Bidang usaha pelayanan seperti perbankan, angkutan, asuransi, atau penyimpanan.

c. Perencanaan dan strategi pemasaran

d. Keuangan, akuntansi dan perpajakan

e. Penguatan dan peningkatan likuiditas modal melalui pemupukan modal secara produktif dan progresif serta mencari peluang fasilitasi penguatan permodalan dari lembaga pembiayaan ;

f. Pencarian peluang pasar melalui pengembangan jejaring dan kemitraan dengan pihak lain yang memiliki kesamaan visi dalam mengembangkan usaha.

Monitoring dan Evaluasi

Monitoring dan evaluasi koperasi tani dilakukan oleh kelembagaan penyuluhan atau kelembagaan yang membidangi penyuluhan serta di setiap jenjang wilayah dengan ruang lingkup diantaranya :

a. Keragaan dan kesiapan gapoktan yang memenuhi persyaratan untuk dikembangkan kapasitasnya menjadi koperasi tani;

b. Proses musyawarah/rembug gapoktan untuk menyepakati pemilihan dan pembentukan koperasi tani;

c. Penyiapan dokumen-dokumen kelengkapan pembentukan koperasi seusai dengan persyaratan;

d. Jumlah koperasi tani yang terbentuk;

e. Penguatan kapasitas manajerial usaha koperasi tani;

f. Jumlah koperasi tani yang melakukan jejaring dan kemitraan usaha dengan pihak lain;

Berdasarkan uraian di atas maka kegiatan pengabdian dilanjutkan dengan memberikan pemahaman tentang prosedur pembentukan koperasi. Materi prosedur pembentukan koperasi ini meliputi: dasar hukum koperasi; tahapan pengajuan koperasi, rapat pembentukan, anggaran dasar, dan pengajuan berkas persyaratan serta peninjauan lapangan oleh tim badan hukum koperasi. (power point terlampir).

\section{KESIMPULAN}

1) Adanya pertanian terpadu wira tani para petani yang tergabung dalam kelompok tersebut memperoleh produktivitas yang tinggi, namun demikian mereka kesulitan dalam menyalurkan dan 
mendistribusikan hasil produksi mereka. Maka dari itu mereka perlu diberikan pengetahuan dan keahlian bagaimana mendistribusikan hasil produksi tersebut, karena Para petani masih banyak yang belum memiliki pengetahuan tentang koperasi tujuan dan manfaat koperasi.

2) Upaya pelatihan tentang distribusi dan pengetahuan tentang koperasi memerlukan proses yang cukup lama mengingat daya tangkap para petani dan pengelola Wiratani yang bervariasi, ada yang cepat namun juga ada yang lambat sehingga waktu yang digunakan kurang maksimal. Disamping itu keterbatasan waktu untuk pelaksanaan pelatihan sehingga beberapa materi tidak dapat disampaikan secara detil.

3) Upaya mendirikan koperasi melibatkan instansi/lembaga lain dan memerlukan proses yang cukup lama sehingga target luaran kegiatan pengabdian tidak bisa seluruhnya dicapai pada periode ini.

4) Pada periode ini tim pengabdi hanya mampu melakukan kegiatan pengabdian sampai dengan pendampingan dalam persiapan pendirian koperasi.

\section{DAFTAR PUSTAKA}

Anoraga, P dan Sudantoko, D. (2002) Koperasi Kewirausahaan dan Usaha Kecil. Jakarta: PT. Rineka Cipta,.

Arvareza, D. (2010). Konsep Pembangunan Pertanian Berkelanjutan Dan Pertanian Agropolitan. Fakultas pertanian, Bogor.

Firdaus, M. (2008). Manajemen Agribisnis. Jakarta: Bumi Aksara. 